Perbal: Jurnal Pertanian Berkelanjutan

Volume 10 No.1 Februari 2022

ISSN 2302-6944,e-ISSN2581-1649

\title{
PENGARUH PUPUK ORGANIK CAIR (POC) BATANG PISANG DAN KOMPOS KULIT JENGKOL TERHADAP PERTUMBUHAN DAN HASIL TANAMAN LOBAK PUTIH (Raphanus sativus L.)
}

\author{
The Effect of Liquid Organic Fertilizer (LOF) of Banana Stem and Jengkol Skin Organic \\ Fertilizer on Growth and Production of White Radish (Raphanus sativus L.)
}

\author{
Efrida Lubis $^{1)}$, Risnawati ${ }^{2 *}$, Yudi Widianto ${ }^{3)}$, Mentari Oniva Mulya ${ }^{4)}$ \\ Program Studi Agroteknologi Fakultas Pertanian Universitas Muhammadiyah Sumatera Utara \\ Jl. Kapten Mukhtar Basri No.3, Glugur Darat II, Medan Timur, Kota Medan Sumatera Utara 20238, \\ Indonesia \\ ${ }^{2 *)}$ risnawati@umsu.ac.id
}

\begin{abstract}
ABSTRAK
Tanaman lobak merupakan salah satu sayuran yang belum dibudidayakan secara intensif oleh petani di Indonesia. Padahal lobak memiliki manfaat yang cukup baik untuk kesehatan, diantaranya untuk menekan senyawa kolesterol di dalam makanan sehingga lobak memiliki prospek yang cukup baik untuk dikembangkan. Salah satu usaha untuk meningkatkan produksi lobak adalah memberikan pupuk yang mengandung unsur hara makro dan mikro yang tepat untuk pertumbuhan tanaman. Penelitian ini bertujuan untuk mengetahui pengaruh POC batang pisang dan kompos kulit jengkol terhadap pertumbuhan dan hasil tanaman lobak putih (Raphanus sativus L.). Penelitian ini dilaksanakan pada bulan Januari 2020 sampai bulan April 2020 di Jl. Meteorologi Kecamatan Percut Sei Tuan, Kabupaten Deli Serdang Provinsi Sumatera Utara Medan dengan ketinggian tempat $\pm 27 \mathrm{mdpl}$. Penelitian ini menggunakan Rancangan Acak Kelompok (RAK) Faktorial, terdiri dari 2 faktor yang diteliti dengan 3 ulangan 16 kombinasi dan 48 plot. Faktor pertama: Pemberian POC Batang Pisang $(\mathrm{P})$ terdiri dari 4 taraf yaitu $\mathrm{P}_{0}$ : Kontrol, $\mathrm{P}_{1}: 150 \mathrm{ml} / \mathrm{l}$ air/plot, $\mathrm{P}_{2}: 300 \mathrm{ml} / \mathrm{l}$ air/plot, $\mathrm{P}_{3}: 450 \mathrm{ml} / \mathrm{l}$ air/plot. Faktor kedua : Pemberian Kompos Kulit Jengkol (K) terdiri dari 3 taraf yaitu $\mathrm{K}_{0}$ : Kontrol, $\mathrm{K}_{1}: 0,5 \mathrm{~kg} / \mathrm{plot}, \mathrm{K}_{2}: 1 \mathrm{~kg} / \mathrm{plot}, \mathrm{K}_{3}: 1,5 \mathrm{~kg} / \mathrm{plot}$. Hasil penelitian menunjukkan bahwa POC batang pisang dan kompos kulit jengkol serta kedua interaksi berpengaruh tidak nyata terhadap semua parameter pengamatan.
\end{abstract}

Kata kunci : lobak putih, kompos kulit jengkol, pupuk organik cair batang pisang

ABSTRACT

Radish is one of the vegetables that has not been cultivated intensively by farmers in Indonesia. Even though radishes have benefits that are quite good for health, including to suppress cholesterol compounds in food so that radishes have good prospects for development. One of the efforts to increase radish production is to provide fertilizers containing appropriate macro and micro nutrients for plant growth. This study aims to determine the effect of POC banana stems and jengkol peel compost on the growth and yield of white radish (Raphanus sativus L.). This research was conducted from January 2020 to April 2020 on Jl. Meteorology Percut Sei Tuan District, Deli Serdang Regency, North Sumatra Province, Medan with an altitude of \pm 27 meters above sea level. This study used a factorial randomized block design (RAK), consisting of 2 factors studied with 3 replications, 16 combinations and 48 plots. The first factor: POC Banana Stem (P) consisted of 4 levels, namely P0: Control, P1: $150 \mathrm{ml} / \mathrm{l}$ water/plot, P2: $300 \mathrm{ml} / \mathrm{l}$ water/plot, P3: $450 \mathrm{ml} / \mathrm{l}$ water/plot. The second factor: Giving Jengkol Skin Compost (K) consisted of 3 levels, namely K0: Control, K1: $0.5 \mathrm{~kg} / \mathrm{plot}, \mathrm{K2:} 1 \mathrm{~kg} / \mathrm{plot}, \mathrm{K} 3: 1.5 \mathrm{~kg} / \mathrm{plot}$. The results showed that the POC of banana stems and jengkol peel compost and the two interactions had no significant effect on all observation parameters.

Keywords: white radish, jengkol skin organic fertilizer, liquid organic fertilizer of banana 
Perbal: Jurnal Pertanian Berkelanjutan

Fakultas Pertanian Universitas Cokroaminoto Palopo

\section{PENDAHULUAN}

Lobak merupakan salah satu jenis sayuran yang belum banyak dikembangkan dalam skala komersial dan intensif. Adapun manfaat tanaman lobak antara lain sebagai penawar rasa makanan terutama menekan senyawa kolesterol (Syaranamual, 2012).

Dalam meningkatkan produksi lobak usaha yang dapat dilakukan adalah dengan menggunakan varietas unggul dan tanah yang subur, serta pupuk organik mengandung unsur hara makro dan mikro yang dibutuhkan untuk pertumbuhan tanaman. Menurut (Nurhayati dkk., 2011), untuk mempertahankan dan meningkatkan bahan organik tanah diperlukan penambahan pupuk organik secara berangsur- angsur.

Pupuk organik terbagi dua yaitu pupuk organik padat dan pupuk organik cair. Pupuk organik mempunyai peran penting dalam memperbaiki sifat fisik, kimia dan biologi tanah. Meskipun kadar hara yang dikandung pupuk organik relatif rendah, namun peranan terhadap sifat kimia tanah, jauh melebihi pupuk kimia buatan (Widowati dkk., 2015).

Salah satu bahan yang dapat dijadikan pupuk organik adalah batang pisang. Batang pisang yang diproses dalam bentuk cair memiliki peranan dalam pertumbuhan vegetatif tanaman dan toleran terhadap penyakit, kadar asam fenolat yang tinggi membantu pengikatan ion-ion $\mathrm{Al}, \mathrm{Fe}$ dan $\mathrm{Ca}$ sehingga membantu ketersediaan fosfor $(\mathrm{P})$ untuk tanaman. Berdasarkan penelitian (Wea, 2018) konsentrasi pupuk organik cair batang pisang memberikan pengaruh paling baik terhadap tanaman okra merah.

Batang pisang dapat dimanfaatkan sebagai bahan utama dalam pembuatan pupuk. Kandungan unsur hara batang pisang yaitu : $\mathrm{NO}_{3}{ }^{-}=3087, \mathrm{NH}_{4}{ }^{-}=1120, \mathrm{P}_{2} \mathrm{O}_{5},=$ 439, $\mathrm{K}_{2} \mathrm{O}=574, \quad \mathrm{Ca}=700, \mathrm{Mg}=800, \mathrm{Cu}$ $=6,8, \mathrm{Zn}=65,2, \mathrm{Mn}=98,3 \mathrm{Fe}=0,09$ (Suhastyo, 2011).

Pupuk organik cair pada batang pisang memiliki peranan dalam masa pertumbuhan vegetatif tanaman. Kadar asam fenolat yang tinggi membantu pengikatan ion-ion sehingga membantu ketersediaan fosfor $(\mathrm{P})$ pada tanah yang berguna pada proses pembungaan dan pembentukan buah pada tanaman. Pada penelitian (Chaniago, 2017) memberikan POC batang pisang dengan dosis $30 \mathrm{ml} /$ liter air pada tanaman kacang hijau dan mendapatkan hasil yang signifikan pada pertumbuhan tanamannya.

Salah satu alternatif pupuk organik padat yang dapat digunakan adalah kompos kulit jengkol. Kulit jengkol mengandung beberapa senyawa-senyawa seperti alkaloid, flavonoid, glikosida antrakinon, tannin, 
triterpenoid, dan saponin yang dimanfaatkan sebagai bioherbisida, selain kandungan diatas, kulit jengkol juga memiliki unsur hara N-total $1,82 \%$, P-total $0,32 \%$, K-total 2,10\%, Ca-total 0,27\%, Mg-total 0,25\%, Ctotal 44,02\%, C/N-total 24,19\% (Hidayah, 2016).

Berdasarkan hal tersebut, maka dilakukan penelitian ini untuk mengetahui pengaruh POC batang pisang dan kompos kulit jengkol terhadap pertumbuhan dan hasil tanaman lobak putih (Raphanus sativus L.).

\section{METODE PENELITIAN}

Penelitian ini dilaksanakan di $\mathrm{Jl}$. Meteorologi Kecamatan Percut Sei Tuan Kabupaten Deli Serdang Provinsi Sumatera Utara Medan dengan ketinggian tempat \pm 27 mdpl pada bulan Januari sampai April 2020.

Bahan - bahan yang digunakan yaitu benih hibrida varietas Ming Ho, insektisida Perfektan 405 EC, kompos kulit jengkol, POC bonggol pisang, $\mathrm{EM}_{4}$, air, bambu, kawat, paranet. Alat - alat yang digunakan yaitu cangkul, parang, meteran, gembor, patok standar, gergaji, scalifer, alat tulis.

Penelitian ini menggunakan Rancangan Acak Kelompok (RAK) Faktorial dengan dua factor yang diteliti yaitu : Faktor POC Batang Pisang (P), terdiri dari 4 taraf yaitu: $\mathrm{P}_{0}$ : Kontrol, $\mathrm{P}_{1}: 150 \mathrm{ml} / \mathrm{l}$ air/plot, $\mathrm{P}_{2}: 300 \mathrm{ml} / 1$ air/plot, $\mathrm{P}_{3}: 450 \mathrm{ml} / 1$ air/plot. Faktor Kompos Kulit Jengkol (K), terdiri dari 4 taraf yaitu: $\mathrm{K}_{0}$ : Kontrol, $\mathrm{K}_{1}$ : $0,5 \mathrm{~kg} / \mathrm{plot}, \mathrm{K}_{2}: 1 \mathrm{~kg} / \mathrm{plot}, \mathrm{K}_{3}: 1,5 \mathrm{~kg} / \mathrm{plot}$. Terdapat 16 kombinasi perlakuan yang diulangi 3 kali dan menghasilkan 48 plot penelitian.

Parameter yang diamati meliputi tinggi tanaman $(\mathrm{cm})$, jumlah daun (helai), panjang umbi $(\mathrm{cm})$, diameter umbi $(\mathrm{cm})$, bobot umbi per, tanaman sampel (g), bobot umbi per plot (g).

\section{HASIL DAN PEMBAHASAN}

Berdasarkan hasil analisis of varians dengan menggunakan Rancangan Acak Kelompok (RAK) dapat diketahui bahwa pemberian POC batang pisang dan kompos kulit jengkol (Gambar 1 dan 2) serta interaksi keduanya (Tabel 1) berpengaruh tidak nyata terhadap pertumbuhan dan hasil tanaman lobak putih.

Pada Gambar 1 dapat dilihat bahwa meskipun tidak berpengaruh nyata, namun secara umum dapat dilihat bahwa pertumbuhan dan hasil tanaman lobak putih paling baik terdapat pada pemberian POC batang pisang dengan dosis $300 \mathrm{ml} / \mathrm{l}$ air/plot $\left(\mathrm{P}_{2}\right)$, sedangkan yang terendah terdapat pada pemberian dosis $450 \mathrm{ml} / \mathrm{l}$ air/plot $\left(\mathrm{P}_{3}\right) \mathrm{POC}$ batang pisang. Hasil tersebut terjadi pada parameter tinggi tanaman, panjang umbi, 
Perbal: Jurnal Pertanian Berkelanjutan

Fakultas Pertanian Universitas Cokroaminoto Palopo

diameter umbi, bobot umbi/tanaman, serta bobot umbi/sampel. Namun pada parameter jumlah daun hasil terbaik justru terdapat pada pemberian $450 \mathrm{ml} / \mathrm{l}$ air/plot $\left(\mathrm{P}_{3}\right)$ dan terendah pada perlakuan $\mathrm{P}_{2}$ (kontrol).
Meskipun demikian, dalam hal ini dapat dilihat bahwa tidak terlihat perbedaan yang cukup signifikan antara tanaman yang diberi perlakuan dengan tanaman yang tidak diberi perlakuan.
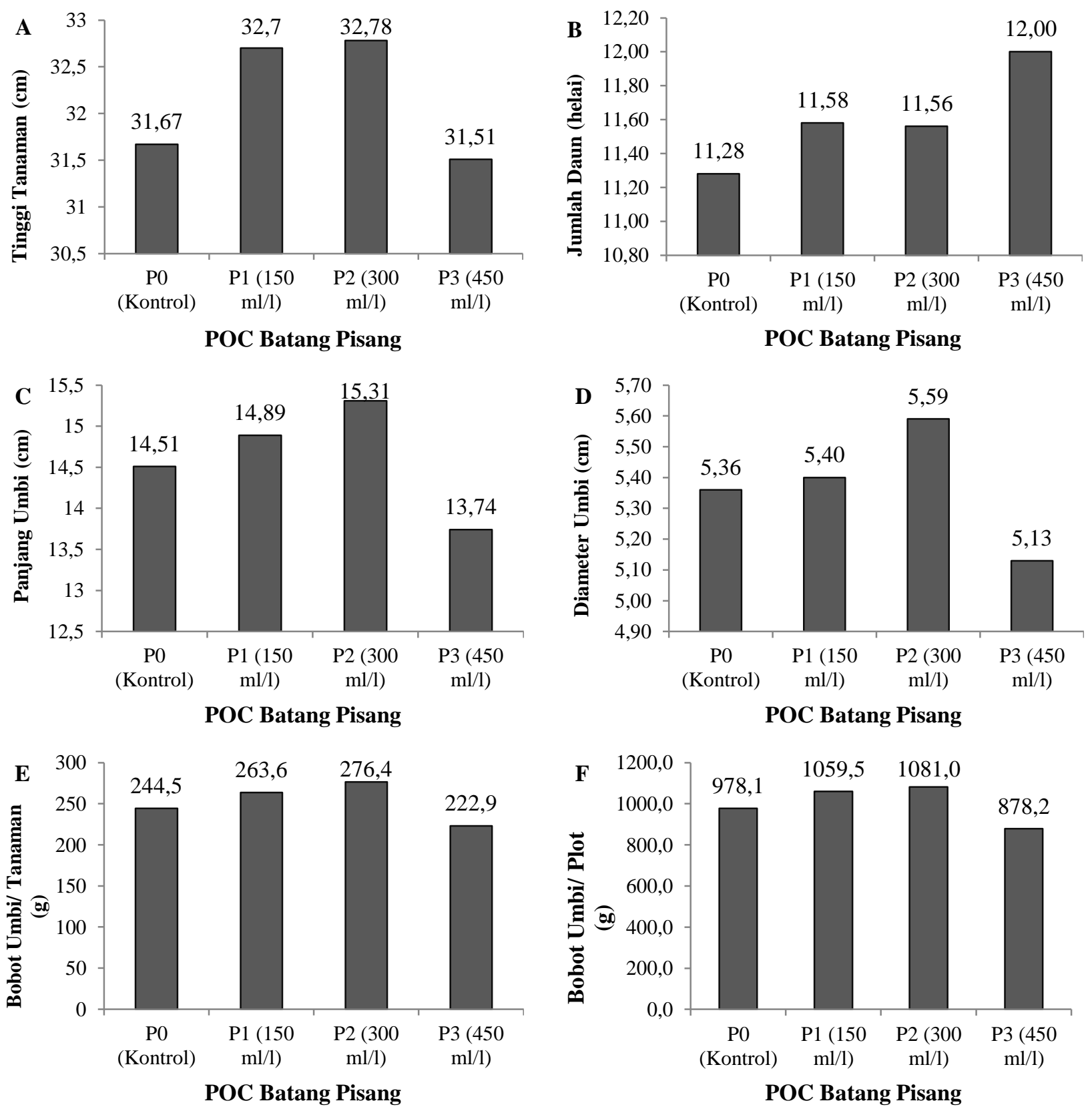

Gambar 1. Diagram rata-rata: (A). Tinggi Tanaman, (B). Jumlah Daun, (C). Panjang Umbi, (D). Diameter Umbi, (E). Bobot Umbi/Tanaman, (F). Bobot Umbi/Plot dengan dengan POC batang pisang terhadap pertumbuhan dan produksi tanaman lobak. 

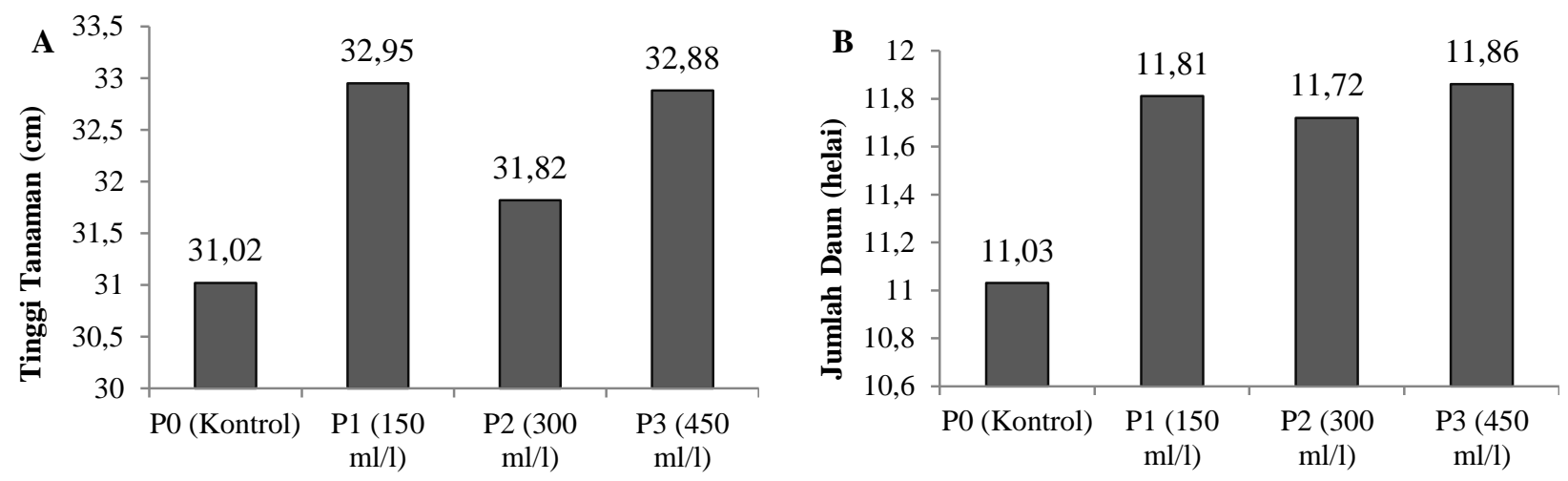

Kompos Kulit Jengkol

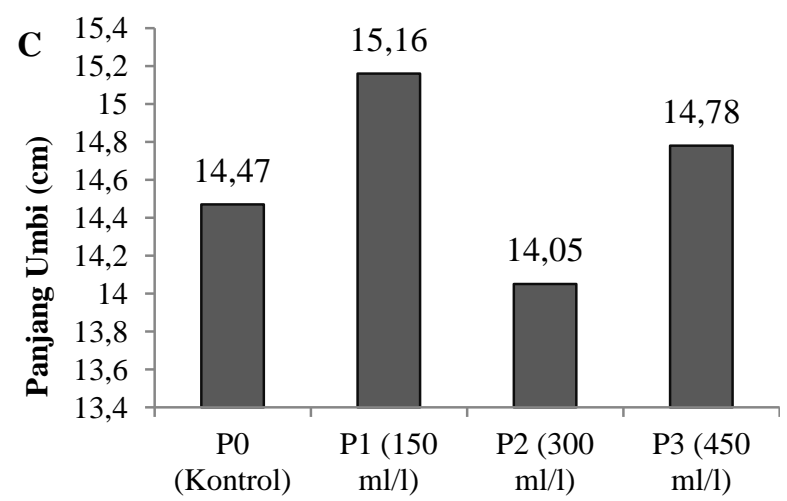

Kompos Kulit Jengkol

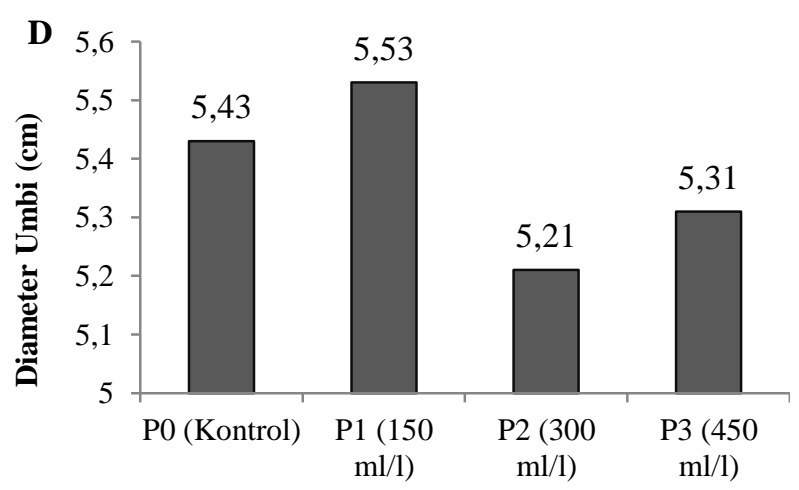

Kompos Kulit Jengkol

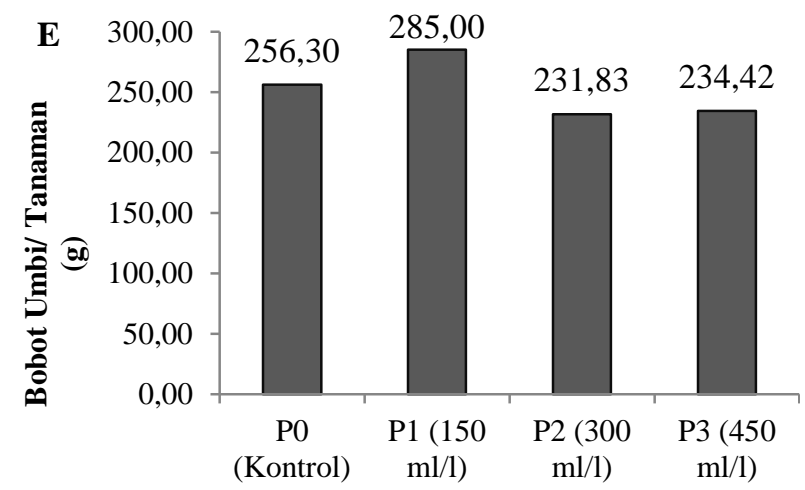

Kompos Kulit Jengkol

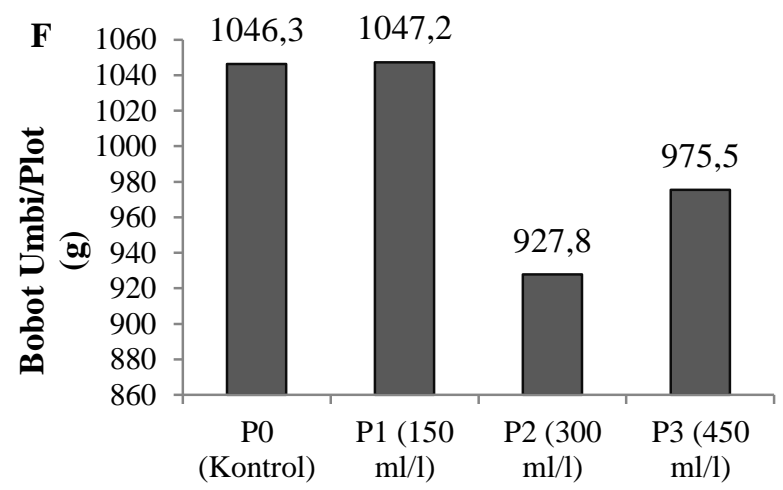

Kompos Kulit Jengkol

Gambar 2. Diagram rata-rata: (A). Tinggi Tanaman, (B). Jumlah Daun, (C). Panjang Umbi, (D). Diameter Umbi, (E). Bobot Umbi/Tanaman, (F). Bobot Umbi/Plot dengan dengan kompos kulit jengkol terhadap pertumbuhan dan produksi tanaman lobak.

Pada Gambar 2 dapat dilihat bahwa, perlakuan kompos kulit jengkol dengan dosis pemberian $0,5 \quad \mathrm{~kg} / \mathrm{plot} \quad\left(\mathrm{K}_{1}\right)$ memberikan efek pertumbuhan tanaman dan hasil yang paling baik terhadap lobak putih, sedangkan yang terendah terdapat pada tanaman yang tidak diberi kompos kulit jengkol $\left(\mathrm{K}_{0}\right)$ untuk parameter tinggi tanaman dan jumlah daun, dan pada dosis $1,0 \mathrm{~kg} / \mathrm{plot}$ $\left(\mathrm{K}_{2}\right)$ untuk parameter panjang umbi, 
Perbal: Jurnal Pertanian Berkelanjutan

Fakultas Pertanian Universitas Cokroaminoto Palopo

diameter umbi, bobot umbi/tanaman, serta

pada pemberian $1,5 \mathrm{~kg} / \mathrm{plot}\left(\mathrm{K}_{3}\right)$ kompos bobot umbi/sampel. Namun pada parameter kulit jengkol.

jumlah daun hasil terbaik justru terdapat

Tabel 1. Data rataan pertumbuhan dan hasil tanaman lobak putih pada kombinasi pemberian POC batang pisang dengan kompos kulit jengkol

\begin{tabular}{|c|c|c|c|c|c|c|}
\hline Perlakuan & $\begin{array}{l}\text { Tinggi } \\
\text { Tanaman } \\
(\mathrm{cm})\end{array}$ & $\begin{array}{l}\text { Jumlah } \\
\text { Daun } \\
\text { (helai) }\end{array}$ & $\begin{array}{l}\text { Panjang } \\
\text { Umbi } \\
(\mathrm{cm})\end{array}$ & $\begin{array}{l}\text { Diameter } \\
\text { Umbi } \\
(\mathrm{cm})\end{array}$ & $\begin{array}{l}\text { Bobot } \\
\text { Umbi/ } \\
\text { Tanaman } \\
\text { (g) }\end{array}$ & $\begin{array}{l}\text { Bobot } \\
\text { Umbi/ } \\
\text { Sampel } \\
\text { (g) }\end{array}$ \\
\hline $\mathrm{P}_{0} \mathrm{~K}_{0}$ & 29.02 & 10.00 & 14.18 & 5.04 & 220.30 & 847.33 \\
\hline $\mathrm{P}_{0} \mathrm{~K}_{1}$ & 33.11 & 11.56 & 14.20 & 5.63 & 288.00 & 1102.30 \\
\hline $\mathrm{P}_{0} \mathrm{~K}_{2}$ & 31.36 & 11.78 & 14.30 & 5.51 & 266.80 & 1022.30 \\
\hline $\mathrm{P}_{0} \mathrm{~K}_{3}$ & 33.19 & 11.78 & 15.34 & 5.27 & 203.10 & 940.33 \\
\hline $\mathrm{P}_{1} \mathrm{~K}_{0}$ & 31.53 & 11.67 & 14.60 & 5.74 & 272.20 & 1262.60 \\
\hline $\mathrm{P}_{1} \mathrm{~K}_{1}$ & 33.26 & 11.89 & 16.83 & 5.64 & 330.70 & 1148.00 \\
\hline $\mathrm{P}_{1} \mathrm{~K}_{2}$ & 32.84 & 11.22 & 13.32 & 4.81 & 196.60 & 835.00 \\
\hline $\mathrm{P}_{1} \mathrm{~K}_{3}$ & 33.18 & 11.56 & 14.80 & 5.4 & 255.10 & 992.67 \\
\hline $\mathrm{P}_{2} \mathrm{~K}_{0}$ & 31.91 & 10.78 & 15.79 & 5.38 & 274.50 & 1120.00 \\
\hline $\mathrm{P}_{2} \mathrm{~K}_{1}$ & 33.63 & 11.56 & 15.43 & 5.86 & 306.50 & 1071.60 \\
\hline $\mathrm{P}_{2} \mathrm{~K}_{2}$ & 31.95 & 12.00 & 14.96 & 5.52 & 255.80 & 996.00 \\
\hline $\mathrm{P}_{2} \mathrm{~K}_{3}$ & 33.62 & 11.89 & 15.08 & 5.61 & 268.70 & 1136.60 \\
\hline $\mathrm{P}_{3} \mathrm{~K}_{0}$ & 31.61 & 11.67 & 13.30 & 5.56 & 258.10 & 959.00 \\
\hline $\mathrm{P}_{3} \mathrm{~K}_{1}$ & 31.79 & 12.22 & 14.18 & 4.99 & 215.00 & 863.33 \\
\hline $\mathrm{P}_{3} \mathrm{~K}_{2}$ & 31.13 & 11.89 & 13.61 & 5.01 & 207.80 & 858.00 \\
\hline $\mathrm{P}_{3} \mathrm{~K}_{3}$ & 31.51 & 12.22 & 13.89 & 4.97 & 210.60 & 832.60 \\
\hline
\end{tabular}

POC batang pisang serta kompos kulit jengkol diketahui mengandung unsur hara seperti nitrogen, fosfor dan juga kalium. Namun jika pemberiannya tidak tepat waktu dan dosis yang benar maka efek yang dihasilkan juga tidak akan maksimal. Pada dasarnya pemberian pupuk dengan dosis yang tepat dan pada waktu yang tepat akan memberikan hasil yang baik terhadap pertumbuhan tanaman. Hal ini sejalan dengan pernyataan dari Panggabean dan
Purwono (2017) yang menyatakan bahwa keefektifan dan efisiensi pemupukan ditentukan oleh pengelolaan pemupukan yang tepat. Pemupukan yang efektif dan efisien mengacu pada konsep 4T yaitu: tepat jenis, tepat dosis, tepat dan tepat cara. Lebih lanjut (Novizan, 2007) menyatakan bahwa dengan cukupnya kebutuhan hara tanamaan baik unsur makro maupun mikro, akan membantu metabolisme tanaman berjalan lancar, selanjutnya akan berguna dalam 
memacu pertumbuhan tanaman, baik vegetatif maupun generatif.

Tanaman membutuhkan unsur hara dengan jumlah yang berbeda - beda pada setiap fase pertumbuhannya. Pada saat tanaman berada pada fase vegetatif, tanaman memang membutuhkan unsur hara seperti nitrogen, fosfor, serta kalium untuk memacu pertumbuhannya dan salah satu unsur hara yang paling berperan terhadap pertumbuhan panjang tanaman adalah unsur nitrogen. Mardianto (2014) menyatakan bahwa pertumbuhan vegetatif dalam suatu tanaman pada dasarnya banyak dipengaruhi oleh komponen hara yang diberikan pada tanaman. Nitrogen berfungsi untuk mempercepat proses pertumbuhan seperti pembelahan sel dan perpanjangan sel sehingga meningkatkan tinggi tanaman. Lebih lanjut Liferdi, (2010) menyatakan bahwa fosfor dibutuhkan oleh tanaman untuk pembentukan sel pada jaringan akar dan tunas yang sedang tumbuh serta memperkuat batang, sehingga tidak mudah rebah pada ekosistem alami.

Namun tanaman muda atau pada fase vegetatif membutuhkan unsur hara tidak sebanyak pada fase generatif. Hal ini sesuai dengan pendapat (Djunaedy, 2009) yang menyatakan bahwa tanaman muda menyerap unsur hara dalam jumlah yang sedikit, sejalan dengan pertumbuhan tanaman, kecepatan penyerapan unsur hara pertanaman akan meningkat. Lebih lanjut (Sutedjo dan Kartasapoetra, 1995) menyatakan bahwa kebutuhan tanaman terhadap bermacam-macam unsur hara selama pertumbuhan dan perkembangannya tidaklah sama, membutuhkan waktu yang berbeda dan tidak sama banyaknya. Sehingga dalam hal pemupukan, sebaiknya diberikan pada waktu/saat tanaman memerlukan unsur hara secara tepat agar pertumbuhan dan perkembangannya berlangsung dengan baik.

Terlihat bahwa baik pertumbuhan maupun hasil dari umbi tanaman lobak putih pada masing - masing taraf perlakuan tidak menunjukkan hasil yang jauh berbeda sehingga dapat dikatakan bahwa tidak ada efek yang ditimbulkan dari perlakuan yang diberikan. Hal ini tidak hanya karena faktor lingkungan yang kurang mendukung pertumbuhan tanaman namun juga diduga karena pemberian kedua jenis pupuk tersebut belum mencukupi kebutuhan unsur hara tanaman lobak putih terlebih lagi ketika memasuki fase pembentukan umbi. Hal ini sesuai dengan pernyataan dari Shella (2013) menjelaskan bahwa hasil tanaman ditentukan oleh proses-proses yang mengendalikan produksi antara lain pasokan 
Perbal: Jurnal Pertanian Berkelanjutan

Fakultas Pertanian Universitas Cokroaminoto Palopo

nutrisi, mineral dan hasil fotosintesis. Peningkatan aktivitas metabolisme berarti dapat meningkatkan proses pembentukan protein yang terbentuk, kemudian ditransfer ke umbi sebagai cadangan makanan, sehingga makin besar cadangan makanan yang terbentuk dalam umbi, semakin besar pula ukuran umbi yang dihasilkan tanaman.

Terdapat hubungan antara pertumbuhan vegetatif dengan jumlah buah/tanaman dimana nutrisi hanya akan ditranslokasikan menjadi buah jika pertumbuhan vegetatif sudah tercukupi. Hal ini sesuai dengan pernyataan dari Gardner et al., (1991) yang menjelaskan bahwa pertumbuhan buah menuntut nutrea mineral yang banyak menyebabkan terjadinya mobilisasi dan transport dari bagian vegetatif ke tempat perkembangan umbi.

\section{KESIMPULAN}

Berdasarkan hasil penelitian yang telah dilakukan menunjukkan bahwa pemberian POC batang pisang dan kompos kulit jengkol tidak berpengaruh nyata terhadap pertumbuhan dan hasil lobak putih. Kombinasi perlakuan POC batang pisang dengan kompos kulit jengkol tidak memberikan interaksi terhadap semua parameter pertumbuhan dan hasil lobak putih.

\section{DAFTAR PUSTAKA}

Chaniago N. (2017). Respon Pemberian Pupuk Organik Cair (POC) Bonggol Pisang dan Sistem Jarak Tanam terhadap Pertumbuhan dan Produksi Kacang Hijau (Vigna radiata L. Willczek). Jurnal Penelitian Pertanian BERNAS. Volume 13 No.1, Fakultas Pertanian Universitas Asahan, ISSN 0216-7689.

Djunaedy, A. (2009). Pengaruh Dosis Pupuk Bokashi terhadap Pertumbuhan dan Hasil Kacang Panjang (Vigna sinensis L.). Jurnal Agrivigor. Vol 2 (1): 42-46.

Gardner . FP.,R. B and R.L Mitchel. (1991). Pysiology of Crop Plants (Fisiologi Tanaman Budidaya, alih bahasa oleh Susilo). UI Press. Jakarta.

Hidayah, N. (2016). Pemanfaatan Limbah Kulit Jengkol Sebagai Bahan Baku Kompos dan Biochar dalam Meningkatkan Pertumbuhan dan Produksi Tanaman Bawang Merah (Allium ascalonicum L. ). Universitas Medan Area.

Liferdi. (2010). Efek Pemberian Fosfor terhadap Pertumbuhan dan Status Hara pada Bibit Manggis. Jurnal Hortikultura. Vol. 20 (1).

Mardianto, R. (2014). Pertumbuhan dan Hasil Cabai (Capsicum annum L.) dengan Pemberian Pupuk Organik Cair Daun Tithonia dan Gamal. Jurnal Pertanian. Vol 1 No. 1.

Novizan. (2007). Petunjuk Pemupukan yang Efektif. Agromedia Pustaka. Jakarta.

Nurhayati, Ali Jamil, dan Rizqi Sari Anggraini, (2011). Potensi Limbah Pertanian sebagai Pupuk Organik Lokal di Lahan Kering Dataran Rendah Iklim Basah. Iptek Tanaman Pangan. Vol. 6 No. 2 - 2011.

Panggabean, SM. dan Purwono. (2017). Manajemen Pemupukan Tanaman Kelapa Sawit (Elaeis guineensis Jacq.) di 
Pelantaran Agro $\quad$ Estate, Kalimantan Tengah. Bul. Agrohorti. Vol 5 (3) : 316324 (2017).

Shella, AJW. (2013). Pengaruh Pemupukan Phonska dan Pupuk Kandang Ayam terhadap Hasil Mentimun (Cucumis sativus, L.) pada Tanah Podsolik Merah Kuning. Jurnal Agripeat. Universitas Palangka Raya. Kalimantan Tengah.

Suhastyo. (2011). Studi Mikrobiologi dan Sifat Kimia Mikroorganisme Lokal yang Digunakan pada Budidaya Padi Metode SRI (System of Rice Intenssification). [Tesis]. Bogor (ID): Institut Pertanian Bogor.

Sutedjo, MM., AG. Kartasapoetra. (1995). Pupuk dan Cara Pemupukan. PT. Bina Aksara. Jakarta.

Syaranamual, S. (2012). Pengaruh Kombinasi Beberapa Jenis Bokashi dan Mulsa terhadap Hasil Lobak. Jurnal AGROTEK. Vol.3, No.1 Januari 2012. ISSN s1907039X.

Wea, K. M. (2018). Pengaruh Pupuk Organik Cair Bonggol Pisang Kepok (Musa Acuminate L.). Terhadap Pertumbuhan Tanaman Okra Merah (Abelmoschus caillei). Skripsi. Universitas Sanata Dharma Yogyakarta Hal 20.

Widowati, R. L., Wiwik, H dan Husnain. (2015). Peranan Pupuk Organik dalam Peningkatan Produktivitas Tanah dan Tanaman. Jurnal Sumber Daya Lahan. Vol. 9 No. 2.ISSN 1907-0799. 